\title{
The antimicrobial efficacy of Lippia alba essential oil and its interaction with food ingredients
}

\author{
Terezinha Feitosa Machado ${ }^{1}$, Nádia Accioly P. Nogueira ${ }^{2}$, \\ Rita de Cássia Alves Pereira ${ }^{1}$, Cívita Teixeira de Sousa ${ }^{2}$, \\ Valéria Chaves Vasconcelos Batista ${ }^{2}$ \\ ${ }^{1}$ Embrapa, Fortaleza, CE, Brazil. \\ ${ }^{2}$ Departamento de Análises Clínicas e Toxicológicas, Universidade Federal do Ceará, \\ Fortaleza, CE, Brazil.
}

Submitted: November 24, 2011; Approved: September 9, 2013.

\begin{abstract}
The objective of this study was to evaluate the antimicrobial potential of Lippia alba essential oil $(\mathrm{EOLa})$ and to investigate the effect of food ingredients on its efficacy. The antimicrobial potential of the oil was determined by the presence or absence of inhibition zones, minimum inhibitory concentration (MIC) and minimum bactericidal concentration (MBC) against Escherichia coli, Listeria innocua, Listeria monocytogenes, Pseudomonas aeruginosa, Salmonella choleraesuis and Staphylococcus aureus. The effect of food ingredients and the $\mathrm{pH}$ on the antimicrobial efficacy of oil was assessed by monitoring the maximum growth rate of Listeria monocytogenes in model media. The model media included potato starch $(0,1,5$ or $10 \%)$, beef extract $(1,5,3,6$ or $12 \%)$, sunflower oil $(0$, 5 or $10 \%$ ) and TSB broth at $\mathrm{pH}$ levels of $4,5,6$ or 7 . The EOLa showed efficacy at all concentrations $(50 \%, 25 \%, 6.25 \%, 3 \%, 1.5 \%, 0.8 \%, 0.4 \%$ and $0.2 \%)$ evaluated, against all bacterial species, Gram-positive and Gram-negative. The antimicrobial efficacy of EO was found to be a function of ingredient manipulation. Proteins and lipids had a negative impact on the oil effectiveness, indicating the protective action of both on the microbial specie tested. On the contrary, at the highest concentration of starch $(10 \%)$, the lower rate growth of L. monocytogenes was detected, therefore indicating a positive effect of carbohydrates on the oil effectivenes. Regarding the $\mathrm{pH}$, the studies showed that the rate of microbial growth increased with increasing $\mathrm{pH}$. It was concluded that the use of EOLa is more effective control pathogenic and spoilage bacteria when applied to starchy foods under an acidic $\mathrm{pH}$.
\end{abstract}

Key words: essential oil, antimicrobial, food ingredient.

\section{Introduction}

Ensuring food safety while at the same time meeting the demands for nutritional conservation attributes and quality have driven the search for the development of alternative methods for food preservation. These increasing demands open new perspectives for the use of natural preservatives derived from plants, animals or microorganisms (Tiwari et al., 2009). Addition of antimicrobial compounds to processed or non-processed foods, prolong their shelf life by reducing the microbial viability or growth rate (Beuchat and Golden, 1989).
Originally, the herbs and spices were used to change or improve the taste and flavor of food. However, products of secondary metabolism of plants, such as essential oils (EOs), naturally play an important role in the protection of plants against infectious agents (Bakkali et al., 2008). Many of the constituents of these oils are known to delay or inhibit the growth of bacteria, fungi, viruses and insects (Burt and Reinders, 2003, Chorianopoulos et al., 2008).

Lippia alba (Mill.) N. E. Brown (Verbenaceae) is a plant native from South America, popularly known as field lemon balm, bush lemon balm, Brazilian lemon balm, field

Send correspondence to T.F. Machado. Embrapa, Rua Dra. Sara Mesquita 2.270, 60511-110 Fortaleza, CE, Brazil. E-mail: terezinha.feitosa@embrapa.br. 
rosemary, wild lemon balm and false Melissa among others (Biasi and, Costa, 2003). Leaves and roots of the plant are used in folk medicine in various forms. It is used for the treatment of gastric diseases, antipyretic diseases, as analgesic and as sedative (Barbosa Filho et al., 2006; Julião et al., 2003). Among the secondary metabolites reported for this species, the essential oil, which constituents include mono and sesquiterpenes, is highlighted (Pascual et al., 2001). Ethanolic extracts of its leaves have been described to possess antimicrobial activity against Staphylococcus aureus (Sena Filho et al., 2006) and different others microorganisms (Aguiar et al., 2008), while the EO was characterized to with activity against Bacillus subitilis, Enterococcus faecalis (Alea et al., 1997), Candida albicans (Duarte et al., 2005), C. parapsilosis, C. krusei, Aspergillus flavus and A. fumigatus (Mesa-Arango et al., 2009).

Because they are devoid of toxic actions, lemon balm herb infusions can be consumed in high doses (Matos, 1998) and its EO is promising for the control of pathogenic and spoilage food microorganisms. Thus, the objective of this study was to evaluate the efficacy $L$. alba essential oil against food spoilage and foodborne pathogenic bacteria and investigate the effect of food ingredients on its efficacy.

\section{Materials and Methods}

\section{Plant material}

Samples of leaves of Lippia alba (MILL.) N.E.Brown (Verbenaceae) were obtained from plant matrices from a medicinal garden belonging to Embrapa Tropical Agroindustry. Part of the raw material was dehydrated in a tray dryer with air circulation at temperatures of $30^{\circ} \mathrm{C}$ for $24 \mathrm{~h}$ (Barbosa and Barbosa, 2006). A voucher specimen of the plant was deposited in Embrapa's Genetic Resources and Biotechnology Herbarium under the number CEN 73.791.

\section{Essential oil extraction}

The plant material, fresh and dried leaves, was submitted to hydro-distillation for $4 \mathrm{~h}$ using a Clevenger-type apparatus. The essential oil (EO) separated by centrifugation was subjected to drying with $\mathrm{Na}_{2} \mathrm{SO}_{4}$. The obtained oil was transferred to amber glass bottles with lids and stored at $2{ }^{\circ} \mathrm{C}$ until analyses (Craveiro et al., 1976).

\section{Gas chromatographic (GC) and gas chromatographic mass spectrometry (GC-MS) analysis}

The percentage composition of essential oil was determined by GC-FID and the compounds were identified by GC-MS. GC analysis was carried out on a Shimadzu 2010 Gas Chromatograph equipped 2010 Gas Chromatograph equipped with an FID and $25 \mathrm{~m} \times 0.25 \mathrm{~mm} \times 0.25 \mu \mathrm{m}$ WCOT column coated with diethylene glycol (AB-Innowax, 7031428, Japan). Both injector and detector (FID) temperatures were maintained at $260{ }^{\circ} \mathrm{C}$. Helium was used as carrier gas at a flow rate of $3.0 \mathrm{~mL} / \mathrm{min}$ at a column pressure of $152 \mathrm{kPa}$. Samples $(0.2 \mu \mathrm{L})$ were injected into the column with a split ratio of 100:1. Component separation was achieved following a linear temperature program of $60-260{ }^{\circ} \mathrm{C}$ at $3{ }^{\circ} \mathrm{C} / \mathrm{min}$ and then held at $260^{\circ} \mathrm{C}$ for $10 \mathrm{~min}$, with a total run time of $76 \mathrm{~min}$. The percentage composition was calculated using peak normalization method assuming equal detector response. The samples were then analysed on same Shimadzu instrument fitted with the same column and following the same temperature program as above and the MS parameters used were: Ionisation Voltage (EI) $70 \mathrm{eV}$, peak width $2 \mathrm{~s}$, mass range $40-700 \mathrm{~m} / \mathrm{z}$ and detector voltage $1.5 \mathrm{~V}$. Peak identification was carried out by comparison of the mass spectra with mass spectra available on database of NIST05, WILEY8 libraries and those of pure standards.

\section{Microorganisms}

The bacterial, pathogenic and spoilage food microorganisms employed in this study were Escherichia coli ATCC 10536, Listeria innocua ATCC 19115, Listeria monocytogenes ATCC 33090, Pseudomonas aeruginosa ATCC 9027, Salmonella choleraesuis ATCC 10708 and Staphylococcus aureus ATCC 6538P. All cultures were maintained at $-80{ }^{\circ} \mathrm{C}$ in brain and heart infused broth (BHI, Merk, Marcy l'Etoile, France) containing 10\% glycerol. The cultures were prepared by subculturing $100 \mu \mathrm{L}$ of each culture stock in $9 \mathrm{~mL}$ of $\mathrm{BHI}$ and incubating at $35^{\circ} \mathrm{C}$ until they reached the exponential growth phase $(12 \mathrm{~h})$. Then, the obtained cultures were diluted in $0.85 \% \mathrm{NaCl}$ solution until turbidity similar to $0.5 \mathrm{McFarland}$ scale (Biomerieux Inc. Darmstadt, Germany), was obtained, corresponding to approximately $1.5 \times 10^{8} \mathrm{cfu} / \mathrm{mL}$.

\section{Antibacterial activity assay}

The Agar diffusion test was performed as previously described (NCCLS, 2003a) with some modifications. $20 \mathrm{~mL}$ of Mueller-Hinton agar (Becton Dickinson, USA) were inoculated with $10^{6} \mathrm{cfu} / \mathrm{mL}$ of one of the indicator strains and then poured onto a Petri dish and allowed to solidify. Wells of $5 \mathrm{~mm}$ diameter were aseptically perforated over the agar surface and $25 \mu \mathrm{L}$ of serially EO dilutions in Tween 80 (Vetec, Duque de Caxias, Rio de Janeiro, Brazil) $1 \%$, were added to the wells. The plates were kept at room temperature to allow dispersal and subsequently incubated under optimal conditions for growth of the target strains. The antimicrobial activity was visually evaluated as inhibition zones surrounding the wells. Sterile solutions of Tween 80 1\% and amikacin (Sigma-Aldrich Co., St. Louis, MO, USA) $1.2 \mathrm{mg} / \mathrm{mL}$ were used as negative and positive controls, respectively. 
Determination of the minimum inhibitory concentration (MIC) and minimum bactericidal concentration (MBC)

MIC values were measured in sterile 96-well microtiter plates (NCCLS, 2003b) with modifications. Bacterial suspensions with cell density were adjusted to $10^{8} \mathrm{cfu} / \mathrm{mL}$, as previously described and were diluted in sterile BHI broth until $10^{6} \mathrm{cfu} / \mathrm{mL}$ was reached. The wells were added with $80 \mu \mathrm{L}$ of microbial suspensions, $100 \mu \mathrm{L}$ of BHI broth (Merck) and $20 \mu \mathrm{L}$ of binary dilutions of the EOLa from fresh and dry leaves (37.5 to $0.29 \mathrm{mg} / \mathrm{mL}$ and 42.74 to $0.33 \mathrm{mg} / \mathrm{mL}$, respectively). In the control wells, $80 \mu \mathrm{L}$ of microbial suspensions, $100 \mu \mathrm{L}$ of BHI broth and $20 \mu \mathrm{L}$ of sterile solution of amikacin $1.2 \mathrm{mg} / \mathrm{mL}$ or Tween $801 \%$ were added. After incubation $\left(35^{\circ} \mathrm{C}\right.$ for $\left.24 \mathrm{~h}\right) 10 \mu \mathrm{L}$ of 3-(4,5-dimethylthiazyl)-2,5-diphenyltetrazolium bromide (MTT, Sigma Aldrich, St. Louis, MO, USA) (dissolved in phosphate buffered saline to a concentration $5 \mathrm{mg} / \mathrm{mL}$ ) was pipetted into each well to stain the living cells. The MIC was defined as the lowest concentration of the test sample that resulted in a complete inhibition of microorganism growth.

The MBC was determined according to the method described by Baron et al. (1994). Aliquots of $50 \mu \mathrm{L}$ were removed from the wells that showed no visible turbidity in the MIC determination test and plated on the surface of plate count agar (Merck). After incubation for $24 \mathrm{~h}$ at $35^{\circ} \mathrm{C}$, the colonies grown on the surface of the agar were counted. The concentration of EOLa able to inhibit the microbial growth to less than $0.1 \%$ of the initial inoculum was considered as the MBC.

\section{Interactive effects of food ingredients and $\mathrm{pH}$}

The effect of food ingredients and $\mathrm{pH}$ on the antimicrobial efficacy of EOs was performed using a range of model media. L. monocytogenes ATCC 33090 was chosen as indicator strain (Gutierrez et al., 2008b). MBC oil, previously established for the microbial species, was used $(0.58 \mathrm{mg} / \mathrm{mL})$. Model media were comprised as the following: (I) water soluble starch from potato $(0,1,5$ or $10 \%$, Difco) in tripticase soy broth (TSB), (II) beef extract (1.5, 3,6 or $12 \%$, Difco) in distilled water and (III) sunflower oil $(0,5$ or $10 \%)$ in TSB. Model media containing starch or beef extract were autoclaved prior to use. For the oil model media, the sunflower oil was autoclaved separately and then added to sterile TSB. Filter-sterilized Tween 80 (Merck) was added at $1 \%$ to facilitate mixing and to stabilize the emulsion. The $\mathrm{pH}$ of each model media was adjusted to 7.2. To determine the effect of $\mathrm{pH}$ on EO efficacy, TSB was adjusted to $\mathrm{pH} 4,5,6$ or 7 with $1 \mathrm{~N} \mathrm{HCl}$ solution.

The growth of L. monocytogenes in each model media containing EO was monitored using 96 well microplates. To the wells, $80 \mu \mathrm{L}$ of each medium, $20 \mu \mathrm{L}$ of EO and $100 \mu \mathrm{L}$ of $10^{6} \mathrm{cfu} / \mathrm{mL}$ of Listeria strain were added, which were assessed in micro plate spectrophotometer (Varian Cary, Cambridge, UK). Positive controls contained model media inoculated with the organism under investigation. Negative controls contained only EO and sterile model media. The survival curves of $L$. monocytogenes in model media were monitored at $490 \mathrm{~nm}$ over a $24 \mathrm{~h}$ period.

\section{Statistical data analyses}

Conventional statistical methods were used to calculate means and standard deviations of two simultaneous assays. To discover whether there were significant differences between the means, it was used Tukey test at $p<0.05$ level.

\section{Results}

\section{Chemical composition of L.alba essential oil}

GC-MS analyses of the oil led to the identification of 36 different components, representing $98.30 \%$ of the total oil. The identified compounds are listed in Table 1. The oil showed a complex mixture of compounds which major constituents were e-citral $(31.57 \%)$, neral $(25.50 \%)$, d-limonemo (14.07\%), germacrene D (5.47\%), b-elemol $(5.37 \%)$, g- terpinen $(4.09 \%)$ and p-cymene $(1.56 \%)$. According to Matos (1996), the majority presence of citral and limonene in oil, classifies it as the chemotype II.

\section{Antibacterial activity assay}

The L. alba EO showed antimicrobial activity at all concentrations tested with a broad spectrum of activity, inhibiting the growth of both Gram positive and Gram negative bacteria (Table 2). S. aureus was the species more sensitive to the oil. The fresh leaf oil was more efficient than the dry leaf oil against the bacterial tested, except for L. innocua.

\section{Determination of minimum inhibitory concentration (MIC) and minimum bactericidal concentration (MBC)}

The values obtained for the MICs and MBCs of EOs from fresh and dried L. alba leaves presented in Table 3 confirm the antimicrobial potential of these substances on Gram positive bacteria. The antimicrobial potential was especially strong against $S$. aureus, which had its growth inhibited when exposed to $0.29 \mathrm{mg} / \mathrm{mL}$ of fresh leaves oil and made it impossible when exposed to $0.33 \mathrm{mg} / \mathrm{mL}$ of EOLa of dried leaves. These results corroborate those obtained by the diffusion method reported previously (Table 1).

\section{Interactive effects of constituents of foods and $\mathrm{pH}$}

The maximum specific growth rate ( $\mu$ max) of $L$. monocytogenes grown in different model media is indicated in Table 4. The antimicrobial effect of EOLa varied depending on the constituent manipulated. Proteins and lipids had a negative impact on the effectiveness of the oil. 
Table 1 - Chemical composition of $L$. alba essential oil.

\begin{tabular}{|c|c|c|}
\hline Compound & $\mathrm{IK}^{1}$ & Composition (\%) \\
\hline$\alpha-$ tujen & 927 & 0.31 \\
\hline$\alpha$ - pineno & 936 & 0.03 \\
\hline Sabinen & 976 & 0.80 \\
\hline 6-Metil-5-hepten-2-one & 987 & 0.12 \\
\hline Mircen & 990 & 0.45 \\
\hline a-Felandren & 1010 & 0.04 \\
\hline 4-Caren & 1021 & 0.13 \\
\hline p-Cimen & 1029 & 1.56 \\
\hline d-Limonen & 1033 & 14.07 \\
\hline g-Terpinen & 1061 & 4.09 \\
\hline 4-Thujanol & 1073 & 0.34 \\
\hline Linalol & 1098 & 0.67 \\
\hline Citronellal & 1151 & 0.07 \\
\hline Borneol & 1174 & 0.10 \\
\hline Z-Geraniol & 1226 & 1.15 \\
\hline Neral & 1238 & 25.50 \\
\hline Carvone & 1247 & 0.84 \\
\hline E-Geraniol & 1250 & 0.77 \\
\hline E-Citral & 1267 & 31.57 \\
\hline a-Copaene & 1372 & 0.07 \\
\hline a-Bourbonene & 1380 & 0.12 \\
\hline b-Cubebene & 1384 & 0.39 \\
\hline a-Cedrene & 1411 & 0.19 \\
\hline b-Cariofilene & 1415 & 0.49 \\
\hline a-Humulen & 1451 & 0.13 \\
\hline allo-Aromadendren & 1455 & 0.19 \\
\hline Germacren D & 1476 & 5.47 \\
\hline Biciclogermacren & 1489 & 0.66 \\
\hline delta-Guaien & 1499 & 0.12 \\
\hline gama-Cadinen & 1508 & 0.50 \\
\hline b-Elemol & 1543 & 5.37 \\
\hline Nerolidol & 1557 & 0.20 \\
\hline Germacren-D-4-ol & 1571 & 0.15 \\
\hline Guaiol & 1590 & 0.56 \\
\hline a-Eudesmol & 1649 & 0.57 \\
\hline Bulnesol & 1666 & 0.63 \\
\hline Total identified & & 98.34 \\
\hline
\end{tabular}

Kovats indexes calculated.

The higher concentration of these constituents, the larger were the averages of microbial growth, indicating protective action of these molecules on species tested. However, for all concentrations of proteins and lipids analyzed, rates of microbial growth were lower than for controls.

In the highest concentration of carbohydrate (10\%) the lowest average growth of $L$. monocytogenes was detected, with significant differences $(\mathrm{p}<0.05)$ on microbial growth of all tested concentrations of starch. When compared to controls, the positive effect of carbohydrate in antimicrobial efficacy of the oil was observed. $L$. monocytogenes growth in the presence of $L$. alba EO decreased with the decreasing $\mathrm{pH}$ of the medium.

\section{Discussion}

The traditional use of plants provides important information for the indication of the type of essential oil to be used for specific purposes in food and in the treatment of infectious diseases. Historically, it has been reported that the EOs have antimicrobial properties (Bajpai et al., 2008; Burt and Reinders, 2003; Chorianopoulos et al., 2008; Hoffman, 1987). However, because of its heterogeneous composition and the antimicrobial activity of many of its components, it seems unlikely that there is only one mechanism of action or that only one of its constituents is responsible for this action (Carson et al., 2002). There is a consensus that the toxicity of essential oils to microorganisms is associated with the lipophilic character and the low molecular weight of their constituents. This allows the essential oil to rapidly cross the cellular membranes, causing changes in its structure and functions, with changes of permeability (Holley and Patel, 2005; Oussalah et al., 2006).

Some studies have shown successful applications of EOs or their compounds, alone or in combinations with other methods of preservation, in the reduction or control of pathogenic and spoilage food microorganisms such as minimally processed vegetables (Gutierrez et al., 2008b), fruits (Martínez-Romero et al., 2007), fish (Mahmoud et al., 2006), meat (Tassou et al., 1995) and milk (Cava et al., 2007).

In this study, the results of antimicrobial screening showed that the $L$. alba $\mathrm{EO}$ has potential antibacterial activity against $E$. coli ATCC 10536, L. innocua ATCC 19115, L. monocytogenes ATCC 33090, P. aeruginosa ATCC 9027, S. choleraesuis ATCC 10708 and S. aureus ATCC 6538P (Table 1). This can be due to the presence of E-citral, neral, d-limonene, germacrene D and g-terpinen, as well as Alpha-pinene, citronellal, a-felandren and a-copaene, major and minor components present in L. alba EO with a potential effect on pathogenic and spoilage food microorganisms (Burt and Reinders, 2003). These results are consistent with those cited by Tavares et al. (Tiwari et al., 2009).

The MIC and MBC values found in this study (Table 2) were higher than those reported by Aquino et al. (2010), which quantified $0.39 \mu \mathrm{g} / \mathrm{mL}$ for $S$. aureus and $12.5 \mu \mathrm{g} / \mathrm{mL}$ for E. coli. However, they were similar to the values reported by Alea et al. (1997). These authors also reported the higher sensitivity of the Gram-positive strain $S$. aureus when compared to the tested Gram-negative strains, as well as a greater resistance of the P. aeruginosa and Salmonella sp strains. 
Table 2 - Zone of Inhibition of the essential oil of fresh and dried Lippia alba leaves.

\begin{tabular}{|c|c|c|c|c|c|c|}
\hline \multirow[t]{2}{*}{ Microorganisms } & \multicolumn{2}{|c|}{ EOLa fresh leaves } & \multicolumn{2}{|c|}{ EOLaII dried leaves } & \multicolumn{2}{|c|}{ Control (Amikacin) } \\
\hline & $\mathrm{IZ}(\mathrm{mm})^{*}$ & Conc $\%$ & $\mathrm{IZ}(\mathrm{mm})^{*}$ & Conc $\%$ & $\mathrm{IZ}(\mathrm{mm}) *$ & Conc $\mathrm{mg} / \mathrm{mL}$ \\
\hline S. auerus & $15.5 \pm 0.7$ & 1.5 & $14.0 \pm 1.4$ & 1.5 & $35.0 \pm 0.0$ & 1.2 \\
\hline L.monocytogenes & $9.0 \pm 1.4$ & 3 & $8.0 \pm 0.0$ & 3 & $35.0 \pm 0.0$ & 1.2 \\
\hline L. innосиа & $10.5 \pm 0.7$ & 3 & $13.0 \pm 1.4$ & 3 & $35.0 \pm 0.0$ & 1.2 \\
\hline E. coli & $10.5 \pm 0.7$ & 25 & $9.0 \pm 1.4$ & 25 & $30.0 \pm 0.0$ & 1.2 \\
\hline P. aeruginosa & $8.0 \pm 0.0$ & 25 & $7.0 \pm 0.0$ & 50 & $30.0 \pm 0.0$ & 1.2 \\
\hline S. choleraesuis & $9.0 \pm 0.0$ & 50 & $9.0 \pm 1.4$ & 50 & $30.0 \pm 0.0$ & 1.2 \\
\hline
\end{tabular}

Mean \pm standard deviation $(\sigma)$ of the halos of growth inhibition $(\mathrm{mm})$ of the two tests. Well diameter: $5 \mathrm{~mm}$. EOLa volume applied to each well: $25 \mu \mathrm{L}$. Negative control: Tween 80 1\%.

Table 3 - Table 3. Inhibitory concentrations (CIM) and minimum bactericidal (CBM) of essential oils of fresh and dry L. alba leaves.

\begin{tabular}{lcccc}
\hline Microorganisms & \multicolumn{2}{c}{ EOLa of fresh leaves } & EOLa of dries leaves \\
\cline { 2 - 3 } S. aureus & MIC $(\mathrm{mg} / \mathrm{mL})$ & 0.29 & MIC $(\mathrm{mg} / \mathrm{mL})$ & MBC $(\mathrm{mg} / \mathrm{mL})$ \\
L. monocytogenes & 0.29 & 0.58 & 0.33 & 0.33 \\
L. innocua & 0.58 & 1.17 & 1.33 & 1.33 \\
E. coli & 0.58 & 1.17 & 1.33 & 1.33 \\
S. choleraesuis & 1.17 & 9.37 & 5.33 & 1.33 \\
P. aeruginosa & 9.37 & 9.37 & 5.34 & 5.34 \\
\hline
\end{tabular}

Controls: (+) amikacin $1.2 \mathrm{mg} / \mathrm{mL}$; (-) Tween 80 1\%

Table 4 - Specific maximum Growth of $L$.monocytogenes in models media containing $0.58 \mathrm{mg} / \mathrm{mL}$ of L.alba $\mathrm{EO}$.

\begin{tabular}{|c|c|c|}
\hline Model media & $\begin{array}{c}\text { Lippia alba } \mu \mathrm{máx} / 24 \mathrm{~h} \\
\left(\mathrm{Abs}_{490 \mathrm{~nm}}\right)\end{array}$ & $\begin{array}{c}\text { Control } \mu \text { máx } / 24 \mathrm{~h} \\
\left(\mathrm{Abs}_{490 \mathrm{~nm}}\right)\end{array}$ \\
\hline \multicolumn{3}{|c|}{ Beef extract (\%) } \\
\hline 1.5 & $0.117 \pm 0.006$ & $0.472 \pm 0.005$ \\
\hline 3.0 & $0.137 \pm 0.003$ & $0.442 \pm 0.050$ \\
\hline 6.0 & $0.160 \pm 0.003$ & $0.479 \pm 0.008$ \\
\hline 12.0 & $0.211 \pm 0.005$ & $0.515 \pm 0.037$ \\
\hline \multicolumn{3}{|c|}{ Starch media $(\%)$} \\
\hline 0.0 & $0.113 \pm 0.006$ & $0.507 \pm 0.066$ \\
\hline 1.0 & $0.147 \pm 0.003$ & $0.615 \pm 0.042$ \\
\hline 5.0 & $0.167 \pm 0.006$ & $0.590 \pm 0.158$ \\
\hline 10.0 & $0.140 \pm 0.003$ & $0.436 \pm 0.025$ \\
\hline \multicolumn{3}{|c|}{$\begin{array}{l}\text { Sunflower oil media } \\
(\%)\end{array}$} \\
\hline 0.0 & $0.116 \pm 0.005$ & $0.620 \pm 0.014$ \\
\hline 5.0 & $0.450 \pm 0.028$ & $0.678 \pm 0.010$ \\
\hline 10.0 & $0.600 \pm 0.019$ & $0.705 \pm 0.028$ \\
\hline \multicolumn{3}{|l|}{$\mathrm{pH}$ in TSB } \\
\hline 4 & $0.089 \pm 0.002$ & $0.251 \pm 0.013$ \\
\hline 5 & $0.097 \pm 0.004$ & $0.452 \pm 0.016$ \\
\hline 6 & $0.093 \pm 0.006$ & $0.519 \pm 0.024$ \\
\hline 7 & $0.100 \pm 0.005$ & $0.588 \pm 0.025$ \\
\hline
\end{tabular}

Means \pm standard deviation $(\sigma)$ values of Abs $490 \mathrm{~nm}$.
Deans et al. (1995) observed that some essential oils seem to be more specific in their antimicrobial activity, exerting greater inhibitory activity against Gram-positive bacteria. The greatest resistance to EOs by Gram-negative bacteria seems to be associated to the structure of their cell wall lipopolysaccharide, which blocks the passage of hydrophobic oils. In this study, all Gram-negative strains tested showed a lower sensitivity to EOLa extracted from fresh leaves. However, when exposed to EO from dried leaves, the strain E. coli was as sensitive as the species of Listeria.

The presence of proteins and lipids determined a reduction in the efficacy of EOLa (Table 3). It is usually assumed that high levels of protein and fat in food protect in some way the bacteria from the EOs action (Tavares et al., 2005). If the EO is dissolved in the lipid phase of the food, it will be relatively less available to act against the bacteria present in the aqueous phase. Gutierrez et al. (2008a) also reported the protective effect of lipids when the effect of EO of oregano and thyme was evaluated on $L$. monocytogenes. However, paradoxically, in the highest concentrations of protein, both EOs were more effective against the microbial species evaluated. Nevertheless, Dorman and Dean (2000) reported that the chemical structure of each component of an EO has direct influence on its antimicrobial activity, which possibly explains these results.

Unlike the protective effect of bacterial growth found for proteins and lipids, a high concentration of starch (10\%) 
determined a positive effect on the action of EOLa, reducing microbial growth. These results corroborate reports of Gutierrez et al. (2008a) and confirm the positive effect of carbohydrates on antimicrobial action of EOLa.

The growth rate of $L$. monocytogenes increased with the $\mathrm{pH}$ increasing. However, for all tested $\mathrm{pHs}$ microbial growth was lower than controls samples without EO.

According to Heinzmann and Barros (2007), one of the native plant species prominent to the development of new drugs is undoubtedly $L$. alba. Based on the results obtained in this study and others cited in the literature, it is possible to show that $L$. alba species is also promising for the development of a new preservative. Employing this species, several preclinical studies have been conducted, showing a number of activities related to its popular use. In parallel, a series of studies showed the effectiveness of essential oils and extracts to control the growth of microorganisms commonly involved in food spoilage and foodborne illnesses. However, despite the promising future, like other native species, $L$. alba requires a greater number of further studies, in order to generate a phytomedicine, herbal preservative or a scientifically proven product, validated to ensure its efficacy, safety and quality.

\section{Conclusions}

The antimicrobial efficacy of the L. alba EO was found to be a function of ingredient manipulation. The antimicrobial activity against $L$. monocytogenes was increased under higher starch concentrations and acidic $\mathrm{pH}$ conditions. High concentrations of protein and sunflower oil have decreased the effectiveness of EO.

\section{References}

Aguiar JS, Costa MCCD, Nascimento SC, Sena KXFR (2008) Atividade antimicrobiana de Lippia alba (Mill.) N. E. Brown (Verbenaceae). Rev Bras Farmacog 18:436-440.

Alea JA, Luis AG, Peréz AR, Jorge MR, Baluja R (1997) Composición y propiedades antibacterianas del aceite esencial de Lippia alba (Mill.) N. E. Br. Rev Cub Farmacol 30:29-35.

Aquino LCL, Santos GG, Trindade RC, Alves J, Santos PO, Alves BP, Blank AF, Carvalho LM (2010) Atividade antimicrobiana dos óleos essenciais de erva-cidreira e manjericão frente a bactérias de carnes bovinas. Alim Nutr 21:529-535.

Bajpai VK, Rahman A, Kang SC (2008) Chemical composition and inhibitory parameters of essential oil and extracts of Nandina domestica Thunb to control foodborne pathogenic and spoilage bacteria. Int J Food Microbiol 125:117-122.

Bakkali F, Averbeck, S, Averbeck D, Idaomar, M (2008) Biological effects of essential oils - A review. Food Chem Toxicol 46:446-475.

Barbosa FF, Barbosa LCA (2006) Influência da temperatura do ar de secagem sobre o teor e a composição química do óleo essencial de Lippia alba (Mill.) N, E. Brown. Quim Nova 29:1221-1225.

Barbosa Filho JM, Medeiros KCP, Diniz MFFM, Batista LM, Athayde Filho PF, Silva MS, Cunha EVL, Almeida JRGS, Quintana Júnior LJ (2006) Natural products inhibitors of the enzyme acetylcholinesterase. Braz J Pharmacog 16:258285.

Baron EJ, Peterson LR, Finegold SM (1994) Diagnostic Microbiology. Mosby St. Louis, Missouri.

Beuchat LR, Golden DA (1989) Antimicrobials occurring naturally in foods. Food Technol 43:134-142.

Biasi LA, Costa G (2003) Propagação vegetativa de Lippia alba. Cien Rural 33:455-459.

Burt SA, Reinders RD (2003) Antibacterial activity of selected plant essential oils against Escherichia coli O157:H7. Lett Appl Microbiol 36:162-167.

Carson CF, Mee BJ, Riley TV (2002) Mechanism of action of Melaleuca alternifolia (tea tree) oil on Staphylococcus aureus determined by time-kill, lysis, leakage and salt tolerance assays and electron microscopy. Antimicrob. Agents Chemother 46:1914-1920.

Cava R, Nowak E, Taboada A, Marin-Iniesta F (2007) Antimicrobial activity of clove and cinnamon essential oils against Listeria monocytogenes in pasteurized milk. J Food Prot 70:2757-2763.

Chorianopoulos NG, Giaouris ED, Skandamis PN, Haroutounian SA, Nychas GJE (2008) Disinfectant test against monoculture and mixed-culture biofilms composed of technological, spoilage and pathogenic bacteria: bactericidal effect of essential oil and hydrosol of Satureja thymbra and comparison with standard acidbase sanitizers. J Appl Micrbiol 104:1586-1869.

Craveiro AA, Matos FJ, Alencar JWA (1976) simple and inexpensive steam generator for essential oils extraction. J Chem Educ 53:652.

Deans SG, Noble RC, Hiltunen R, Wuryani W, Penzes LG (1995) Antimicrobial and antioxidant properties of Syzygium aromaticum (L) Merr Perry: impact upon bacteria, fungi and fatty acid levels in ageing mice. Flavor Fragrance J 10:323328.

Dorman HJD, Deans SG (2000) Antimicrobial agents from plants: antibacterial activity of plant volatile oils. J Appl Microbiol 88:308-316.

Duarte MCT, Figueira GM, Sartoratto A, Rehder VLG, Delarmelina C (2005) Anti-Candida activity of Brazilian medicinal plants. J Ethnopharm 97:305-311.

Gutierrez J, Barry-Ryan C, Bourke P (2008a) The antimicrobial efficacy of plant essential oil combinations and interactions with food ingredientes. Int J Food Microbiol 124:91-97.

Gutierrez J, Rodriguez G, Barry-Ryan C, Bourke P (2008b) Efficacy of plant essential oils against foodborne pathogens and spoilage bacteria associated with ready-to-eat vegetables: Antimicrobial and sensory screening. J Food Prot 71:18461854.

Heinzmann BM, Barros FMC (2007) Potencial das plantas nativas brasileiras para o desenvolvimento de fitomedicamentos tendo como exemplo lippia alba (Mill.) N. E. Brown (Verbenaceae). Saúde 33:43-48.

Hoffman DL (1987) The herb user's guide. Thorsons Publishing Group. Wellingborough, UK.

Holley RA, Patel D (2005) Improvement in shelf-life and safety of perishable foods by plant essential oil and smoke antimicrobials. Food Microbiol 27:273-292.

Julião LS, Tavares ES, Lage CLS, Leitão SG (2003) Cromatografia em camada fina de extratos de três quimiotipos de 
Lippia alba (Mill) N. E. Br. (erva cidreira). Rev Bras Farmacog 13:36-38.

Mahmoud BS, Yamazaki K, Miyashita K, Kawai Y, Shin IS, Suzuki T (2006) Preservative effect of combined treatment with electrolyzed $\mathrm{NaCl}$ solutions and essential oil compounds on carp fillets during convectional air-drying. Int $\mathrm{J}$ Food Microbiol 106:331-337.

Martínez-Romero D, Guillén F, Valverde JM, Bailén G, Zapata P, Serrano M, Castillo S, Valero D (2007) Influence of carvacrol on survival of Botrytis cinerea inoculated in table grapes. Int. J. Food Microbiol 115:144-148.

Matos FJA (1998) Farmácias Vivas. UFC, Ceará.

Mesa-Arango AC, Montiel-Ramos J, Zapata B, Durán C, Betancur-Galvis L, Stashenko E (2009) Citral and carvone chemotypes from the essential oils of Colombian Lippia alba (Mill.) N.E. Brown: composition, cytotoxicity and antifungal activity. Memórias do Instuto Oswaldo Cruz 104:878-884.

National Committee for Clinical Laboratory Standards-NCCLS (2003b) Methods for dilution antimicrobial susceptibility test for bacteria that grow aerobically, Approved Standard.

National Committee for Clinical Laboratory Standards-NCCLS (2003a) Performance Standards for Antimicrobial Disk Susceptibility Tests, Approved Standards.

Oussalah M, Caillet S, Lacroix M (2006) Mechanism of action of Spanish oregano, Chinese cinnamon, and savory essential oils against cell membranes and walls of Escherichia coli O157:H7 and Listeria monocytogenes. J. Food Prot 69:1046-1055.

Pascual ME, Slowing K, Carretero E, Mata DS, Villar A (2001) Lippia: tradicional uses, chemistry and pharmacology: a review. J. of Ethnopharmacol 76:201-14.

Sena Filho JG, Melo JGS, Saraiva AM, Gonçalves AM, Psiottano MNC, Xavier HS (2006) Antimicrobial activity and phytochemical prolife from the roots of Lippia alba (Mill.) N. E. Brown. Braz J Pharmacog 16:506-509.

Tassou C, Drosinos EH, Nychas GJE (1995) Effects of essential oil from mint (Mentha piperita) on Salmonella enteritidis and Listeria monocytogenes in model food systems at $4{ }^{\circ} \mathrm{C}$ and $10{ }^{\circ} \mathrm{C}$. J Appl Bacteriol 78:593-600.

Tavares ES, Julião LS, Lopes D, Bizzo HR, Lage CLS, Leitão SG (2005) Análise do óleo essencial de folhas de três quimiotipos de Lippia alba (Mill.) N. E. Br. (Verbenaceae) cultivados em condições semelhantes. Rev Bras Farmacogn 5:1-5.

Tiwari BK, Valdramidis VP, O' Donnell CP, Muthukumarappan K, Bourke P, Cullen PJ (2009) Application of natural antimicrobials for food preservation. J Agric Food Chem 57:5987-6000.

All the content of the journal, except where otherwise noted, is licensed under a Creative Commons License CC BY-NC. 